3. Jason Rudy, Imagined Homelands: British Poetry in the Colonies (Baltimore: Johns Hopkins University Press, 2017).

4. Priya Joshi, In Another Country: Colonialism, Culture and the Novel in India (New York: Columbia University Press, 2002). See also Sukanya Banerjee, Becoming Imperial Subjects: Indians in the Late-Victorian Empire (Durham: Duke University Press, 2010).

5. Chadwick Allen, Trans-Indigenous: Methodologies for Global Native Literary Studies (Minneapolis: University of Minnesota Press, 2012), xx.

6. Allen, Trans-Idigenous, xix.

7. Jane Stafford, Colonial Literature and the Native Author: Indigeneity and Empire (Basingstoke: Palgrave Macmillan, 2016). See also Coll Thrush, Indigenous London: Native Travelers at the Heart of Empire (New Haven: Yale University Press, 2016).

8. Vine Deloria, Jr., We Talk, You Listen: New Tribes, New Turf (Lincoln: University of Nebraska Press, 1970).

\title{
Empire
}

\section{WILL GLOVINSKY}

MPIRE, like Flaubert's ideal author, has a way of seeming everywhere
present yet scarcely visible in much Victorian literature. While review sections of the field's journals attest to robust interest in nineteenthcentury imperialism and settler colonialism, racial and "free trade" ideologies, cosmopolitanisms and oceanic rims, the significance of empire for our reading of Victorian literature has remained more equivocal. Often immured within a sub-canon of important but fairly familiar works, empire-and especially its relation to literary forms and themes-can seem to be a subject more easily discussed at a dedicated conference panel than in an undergraduate survey hoping to demonstrate what is particularly valuable or interesting about nineteenth-century literature, and in particular the novel. Critics may agree that an empire based on a massive, coerced drug trade, indigenous genocide, and the unfree labor of millions was a key socioeconomic factor in nineteenth-century British culture, but it can be difficult at times to see how this history figures in the novel canon's conservative but resilient core of metropolitan, 
mid-century, more-or-less realist fiction. What, really, is the empire to Dorothea Brooke? Why parse indirect rule when there's free indirect style?

It's worth reflecting how much this state of affairs tells us about our own practices of canon formation, based as they are on aesthetic criteria of contemporary pleasurableness, density of meaning, and contestability of interpretation, as well as academics' generic preferences for realism over romance or "serious" over juvenile fiction. If literary critics hardly need reminding that such tastes classify the classifiers, the excising of colonial themes and preferences out of the canon-the neglect of nautical romancers like Frederick Marryat, or G. W. M. Reynolds, who outsold Dickens in India-should cause us to ask why so many authors who wrote about or were widely read in the colonies have been less congenial to academics. ${ }^{1}$

But a second and arguably more critically tractable force behind empire's apparently equivocal relation to nineteenth-century novels may lie in the very methodologies and metaphors we use to apprehend the content of imperialism. In the early 1990s, for instance, several highly influential works construed empire in primarily spatial terms, as the properly geographic extension of political and economic power. Edward Said understandably premised his arguments in Culture and Imperialism on the paramount role of space-"the actual geographic possession of land"-in theorizing empire, and on the corresponding observation that this imperial space is "only marginally visible" in most nineteenth-century fiction. ${ }^{2}$ It thus fell to the critic, Said wrote, "to draw out, extend, give emphasis and voice to what is silent or marginally present" in the novel. ${ }^{3}$ And, in a slightly earlier essay on modernist aesthetics, Fredric Jameson so raised the spatial stakes of criticism as to make empire synonymous with an ungraspable geopolitical totality. For Jameson, "colonialism means that a significant structural segment of the economic system is now located elsewhere, beyond the metropolis." ${ }^{4}$ Critics of imperial literature should then read style (instanced by the Great Northern Road's sublime "infinity" in Howards End) as the textual "marker and substitute" of the global "unrepresentable totality." 5

Following Said and Jameson, a body of remarkable scholarship has retraced empire's previously neglected incursions into the canonical British novel in subplots of imperial travel, in the figure of the colonial émigré or returnee, and in the networks of colonial labor, commodities, and capital that underpin so-called domestic comfort. Understanding when and how the Victorian novel made imperial space visible through 
such geopolitical systems remains a vital critical project, not least because of recent work investigating how imperial "development" devastated and transformed colonial environments. But redoubled attention to textual glimpses of geopolitical totality can also militate against readings of the novel as a whole in itself. As James Buzard has pointed out, "Not merely hypersensitive scrutiny of the novel's peripheries ... but detailed formal analysis of its central structures and language remains indispensable to a globally conscious novel criticism." 6

It is perhaps no coincidence, then, that two important recent books offer thought-provoking models for construing the immanence of empire in the Victorian novel's "central structures." Nathan Hensley's engrossing Forms of Empire investigates how Victorian writers used the resources of plot, narration, meter, and genre to not merely register but also think through the juridical problems of liberal sovereignty and imperial violence. ${ }^{7}$ In The Victorian Geopolitical Aesthetic, meanwhile, Lauren Goodlad persuasively reveals the imperial-capitalist worldedness of seemingly domestic fiction by tracing tropes of collapsed "heirloom" sovereignty from Trollope's Barsetshire to the adultery narratives of Flaubert and Eliot. ${ }^{8}$

Goodlad and Hensley's innovative approaches should prompt us to develop others. What if we envisioned the nineteenth-century novel's engagement with empire not only as the quest for a totalized global system but also as a more limited yet still socially significant "structure of feeling"? How might we map the intimacies, affiliations, prejudices, and conceptual problems that made empire however real and urgent it was for the vast majority of Victorians whose work or travel never carried them to overseas colonies? Such an approach may sound overmodest or even quietist, yet dwelling on the nineteenth-century novel's relative reluctance to provide the totalized global view that twenty-first century critics desire may in fact edge us closer to understanding what the art we study and teach has to tell us about its imperial world. Even when they neglect colonial space and its constitutive violence, canonical Victorian novels may provide uniquely generative literary evidence of imperialism as an affective turbulence, a question of fraught intimacy, or a structure of self-alienation coiled within the conceit of omniscient impersonality. Such avenues of inquiry can connect themes of empire to those aspects of nineteenth-century British fiction that are most generically distinctive: to narrative form, the unspooling of characters' psychologies, to casuistry and ethical commitment. 
The reasons to renew our focus on empire and affect might include insights from the critically undervalued patterns of biography. Most regulars of the nineteenth-century novel syllabus did not spend much time in Britain's empire, yet nearly all had close family members who did: Austen had two brothers in the navy; Gaskell's went missing in India; Dickens packed off two sons to India and another two to Australia; Trollope sent his eldest to New South Wales to raise sheep; Eliot helped establish G. H. Lewes's sons in Natal. Reckoning with Victorian literature's failures and successes in writing the global entails understanding how empire for these novelists (as for millions of their contemporaries) was a family affair, its affective range spanning distant intimacy, the vicarious careerism of hopeful middle-class parents, the gamble (or $5 \%$ guarantee) of colonial investments, the bigoted anxiety over mixed-race marriages. As work by Leela Gandhi, Tanya Agathocleous, Nancy Henry, and Deirdre David demonstrates, thinking about affect, disaffection, domesticity, and gender in relation to empire can illuminate nineteenth-century literature and culture while also helping us to perceive the lived structures of imperial experience and colonial resistance. ${ }^{9}$ If these forms of actually existing imperial consciousness fail to reassemble the British world-system's economic totality or make invisible global space visible, they can return us to what makes the Victorian novel beat by showing how, in the nineteenth century, the personal was already geopolitical.

\section{Notes}

1. Priya Joshi, In Another Country: Colonialism, Culture, and the English Novel in India (New York: Columbia University Press, 2002), 35.

2. Edward W. Said, Culture and Imperialism (New York: Vintage, 1994), 78, 63.

3. Said, Culture, 66.

4. Fredric Jameson, "Modernism and Imperialism," in The Modernist Papers (London: Verso, 2007), 157.

5. Said, Culture, 163.

6. James Buzard, Disorienting Fiction: The Autoethnographic Work of Nineteenth-Century British Novels (Princeton: Princeton University Press, 2009), 42.

7. Nathan K. Hensley, Forms of Empire: The Poetics of Victorian Sovereignty (Oxford: Oxford University Press, 2016). 
8. Lauren M. E. Goodlad, The Victorian Geopolitical Aesthetic: Realism, Sovereignty, and Transnational Experience (Oxford: Oxford University Press, 2015).

9. Leela Gandhi, Affective Communities: Anticolonial Thought, Fin-De-Siècle Radicalism, and the Politics of Friendship (Durham: Duke University Press, 2006); Tanya Agathocleous, "'The Coming Clash of East and West': Syncretism, Cosmopolitanism, and Disaffection in the Colonial Public Sphere," Textual Practice 31, no. 4 (2017): 661-85; Nancy Henry, George Eliot and the British Empire (Cambridge: Cambridge University Press, 2006); and Deirdre David, Rule Britannia: Women, Empire, and Victorian Writing (Ithaca: Cornell University Press, 1995).

\section{Enclosure}

\section{ZACH FRUIT}

$\mathrm{F}^{\mathrm{ROM}}$ the right angle, land enclosure takes on the aspect of the root F of capitalist accumulation. Marx, while suspicious of origin stories, famously identifies land enclosure, and the nascent statist tactics of "conquest, enslavement, robbery, murder, in short, force" that accompany it, as the "original sin" of "so-called primitive accumulation."1 Many historians have identified British land enclosure as a crucial aspect of the eighteenth-century rise of industrial capitalism, while differently theorizing the relationship between the productive dynamics of English agriculture and the multinational circulation of capital. ${ }^{2} \mathrm{~J}$. M. Neeson has given the most textured account of the enclosure of the commons as a decentralized process of expropriation that occasioned a complex array of resistance, ambivalence, and compromise. ${ }^{3}$ The agricultural "improvements" that accompanied enclosure also seem to be imbricated in the enforced migration of agricultural laborers into urban centers and the increasing rate of mechanization that led to the industrial revolution. ${ }^{4}$ Perhaps undertheorized, however, are the visual and aesthetic effects of enclosure, and the innovative literary methodologies that metabolized and disrupted these material transformations. Approaching enclosure as an aesthetic phenomenon rather than an economic process allows for a 